\title{
MENJADI PUSTAKAWAN PROFESIONAL BERSAMA IKATAN PUSTAKAWAN INDONESIA (IPI)
}

\section{Oleh: Dian Hapsari}

\begin{abstract}
Abstrak
Salah satu dampak perkembangan teknologi informasi yang semakin canggih adalah semakin membludaknya arus informasi. Teknologi informasi telah menciptakan era baru dalam masyarakat yakni era masyarakat informasi. Pada era ini, kebutuhan masyarakat terhadap informasi juga semakin meningkat, bahkan bisa diibaratkan bagai udara yang dibutuhkan untuk bernafas. Masyarakat semakin membutuhkan informasi dalam setiap aspek kehidupan. Informasi tidak hanya digunakan sebagai kebutuhan tersier atau sekunder tetapi sudah meningkat menjadi kebutuhan primer, bahkan seringkali informasi digunakan sebagai alat bertahan hidup..
\end{abstract}

Kata Kunci: Pustakawan Profesional, Ikatan Pustakawan Indonesia

\section{A. Latar Belakang}

emakin banyaknya sumber S penghasil informasi, kehadiran informasi menjadi tak terkendali. Semua media berlomba-lomba mengeluarkan informasi dengan berbagai macam slogannya seperti "yang terdepan", "yang tercepat", "yang utama" dan lain sebagainya. Sehingga seringkali seseorang merasa kewalahan dengan berbagai informasi yang diterimanya. Bahkan terkadang saking banyaknya, seseorang dapat memperoleh informasi tentang suatu hal yang sama tetapi bertentangan. Lebih parahnya lagi terkadang seseorang tidak dapat menemukan informasi yang dibutuhkannya karena sudah terlalu pusing dengan terpaan informasi yang diterimanya, akibatnya informasi yang seharusnya bisa berguna bagi seseorang malah bersifat useless. Untuk itulah terdapat lembagalembaga atau institusi yang menyediakan layanan informasi baik yang bersifat profit oriented maupun non- profit oriented yang diharapkan dapat membantu seseorang untuk memperoleh informasi yang tepat sesuai dengan kebutuhannya juga pada saat yang tepat.

Perpustakaan, sebagai salah satu lembaga penyedia informasi, memiliki peran untuk menyediakan informasi yang dibutuhkan oleh penggunanya. Keberadaanya memiliki fungsi sebagai berikut:

\section{Fungsi edukatif/pendidikan \\ Segala koleksi bahan pustaka yang ada di}


perpustakaan dapat digunakan untuk mendukung proses pembelajaran yang pada akhirnya dapat mencapai tujuan pembelajaran tersebut.

2. Fungsi penelitian/research

Perpustakaan sebagai penyedia informasi dengan koleksi yang up to date sehingga dapat digunakan sebagai bahan penelitian

\section{Fungsi pelestarian}

Di dalam fungsi pelestarian ini, perpustakaan berperan sebagai sumber deposit bagi karya-karya ilmiah yang dihasilkan oleh civitas akademika lembaga penaungnya ataupun dapat juga bagi koleksi bahan pustaka yang bersifat langka.

\section{Fungsi Informasi}

Perpustakaan diharapkan dapat menyediakan akses informasi yang dibutuhkan para penggunanya (pemustaka)

\section{Fungsi rekreatif}

Keberadaan perpustakaan juga diharapkan menyediakan koleksi yang bersifat rekreatif sehingga pemustaka yang datang dapat memanfaatkan koleksi ini untuk menemukan ide-ide baru ataupun inovasi.

Dalam era masyarakat informasi saat ini, kehadiran perpustakaan sebagai lembaga penyedia, pengolah dan kemudian menyebarkan informasi harus dapat menjawab segala tantangan. Untuk itulah perpustakaan harus memikirkan bentuk dan ide-ide kreatif yang tepat untuk dapat melaksanakan fungsi-fungsi tersebut diatas agar jangan sampai tertinggal atau bahkan tergilas kemajuan teknologi informasi yang semakin pesat.

\section{B. Pustakawan Sebagai Profesi}

Di dalam perpustakaan, banyak faktor yang memegang peranan penting. Salah satunya adalah faktor pustakawan. Sehebat atau secanggih apapun perpustakaannya apabila tidak didukung oleh Sumber Daya Manusia yang baik, dalam hal ini adalah pustakawannya, tidak akan banyak berarti.

Namun sayangnya, di masyarakat kita keberadaan pustakawan sebagai suatu profesi seringkali tidak diakui di masyarakat. Banyak yang menganggap pekerjaan pustakawan tidak menarik ataupun tidak ada tantangannya sehingga pustakawan tidak pantas disebut sebagai profesi. Imej tentang pustakawan hanyalah sebatas penjaga buku di sebuah gedung, tua, galak dan tidak menarik. Imej seperti inilah yang terkadang membuat pustakawannya malu menyebutkan pekerjaannya. 
Seolah-olah profesi pustakawan adalah profesi "kelas dua". Apabila begitu bagaimana dunia perpustakaan di Indonesia bisa maju jika pustakawannya sering bersifat "malu-malu kucing" dengan profesinya sendiri.

Padahal apabila ditilik lebih jauh, profesi pustakawan sudah ada sejak zaman Mesir Kuno. Bahkan di film-film sejarah, pustakawan sering digambarkan sebagai sosok yang pintar dan sering memegang informasi yang penting. Luar biasa....

Di negara-negara maju yang seringkali menjadi impian dan harapan para pustakawan di Indonesia, pustakawan sudah diakui sebagai suatu profesi. Bagaimana di negara kita?

Menurut Sulistyo Basuki (1993) ada 7 (tujuh) syarat yang harus dipenuhi agar suatu pekerjaan dapat diakui sebagai profesi, yakni:

1) adanya organisasi yang anggotanya terdiri atas profesi sejenis,

2) Mempunyai pendidikan dan ketrampilan khusus,

3) Isi intelektual

4) Berorientasi pada jasa,

5) Mempunyai kode etik ,

6) kemandirian,

7) Status

Sementara, seperti yang diamanatkan dalam UndangUndang No 43 Tahun 2007 tentang
Perpustakaan, pemerintah menetapkan profesi pustakawan sebagai jabatan fungsional. Dalam jabatan fungsional tersebut seorang pustakawan dituntut untuk:

1) memiliki pendidikan, keahlian dan ketrampilan di bidang perpustakaan yang diperoleh melalui pendidikan formal, penataran atau diklat dan sebagainya,

2) memiliki kemandirian, yaitu mampu memimpin diri sendiri, tidak selalu diperintah, tidak diatur oleh pejabat jabatan fungsional lain, menggunakan ilmu pengetahuan, pengalaman dan ketrampilan dalam bekerja

3) dinamis, artinya selalu mengikuti perkembangan dan tuntutan profesi, dan

4) mampu menyesuaikan diri dengan perkembangan sosial dan iptek (Lasa, 1996)

Kembali ke masalah perkembangan teknologi, untuk menjawab berbagai tantangan dalam hal ini adalah kebutuhan masyarakat akan informasi yang semakin tinggi dibutuhkan keberadaan seorang pustakawan profesional.

Bagaimanakah sosok pustakawan yang profesional tersebut, penulis membayangkan sosok pustakawan profesional adalah sebagai berikut: 
(1) Memiliki latar belakang pendidikan yang sesuai kemudian masih mau untuk terus belajar mengenai hal-hal baru untuk meningkatkan pengetahuan, keahlian dan ketrampilan.

(2) Pustakawan harus mempunyai jaringan yang luas. Pustakawan juga manusia, maksudnya pustakawan tidak bisa menangani segala hal tetapi bukan berarti apabila pustakawannya tidak bisa kemudian berhenti, mandek. Sebagai contoh, pustakawan tidak bisa membuat website untuk perpustakaan, maka pustakawan bisa menggunakan jasa seorang ahli informasi teknologi untuk membuatkan website. Atau pun ketika terdapat pemustaka yang meminta suatu informasi yang tidak ada di perpustakaan, dengan jaringan yang luas maka pustakawan bisa mencarikan di tempat lain. Salah satu cara memiliki jaringan yang luas, pustakawan dapat menjadi anggota profesi ataupun turut aktif dalam seminar-seminar.

(3) Pustakawan harus menguasai alat-alat pencari informasi. Sudah bukan jamannya lagi pustakawan "gaptek".

(4) Pustakawan juga menguasai bidang ilmu lain. Misalnya saja pustakawan

memiliki

kemampuan bahasa asing untuk mengolah bahan pustaka yang berasal dari luar negeri. Ataupun pustakawan memiliku ilmu akuntansi yang digunakan dalam kegiatankegiatan administrasi di perpustakaan.

\section{IPI dan Pustakawan}

Seperti telah disebutkan diatas, Salah satu poin agar bisa disebut profesi adalah mempunyai organisasi profesi. Organisasi Profesi sebagaimana diamanatkan dalam UU No 43 Tahun 2007 adalah sebagai berikut:

- pustakawan membentuk organisasi profesi,

- berfungsi memajukan dan memberi perlindungan profesi kepada pustakawan,

- Setiap pustakawan menjadi anggota profesi,

- Organisasi profesi dibina, dikembangkan, difasilitasi oleh Pemerintah, Pemda dan/atau masyarakat

Di Indonesia, profesi pustakawan sebenarnya telah diakui pemerintah melalui SK MENPAN No.18/MENPAN/1988 dan diperbaharui dengan SK MENPAN No. 33/MENPAN/1990, 
yang kemudian diperkuat dengan keputusan-keputusan lain mengenai hak dan kewajiban profesi pustakawan seperti yang juga termaktub dalam UU No 43 Tahun 2007 Tentang Perpustakaan.

Organisasi profesi pustakawan lebih dikenal dengan Ikatan Pustakawan Indonesia atau yang biasa disingkat IPI (yang harus dibaca dengan I-Pe-I). Didirikan pada tanggal 6 Juli 1973 dalam Kongres Pustakawan Indonesia yang diadakan di Ciawi, Bogor, 5-7 Juli 1973. Dari IPI inilah kemudian muncul forum-forum yang berkaitan dengan dunia perpustakaan seperti FP2T (Forum Perpustakaan Perguruan Tinggi), ISIPI dan lain sebagainya.

Namun sayangnya keberadaan organisasi profesi pustakawan masih dirasa kurang terasa manfaatnya bagi para pustakawan karena masih banyak pustakawan yang belum terdaftar bahkan ada juga yang belum tahu tentang IPI. Apalagi kedudukan IPI lebih cenderung mengacu pada profesi pustakawan PNS. Banyak pustakawan di instansi-instansi swasta kurang merasakan manfaatnya ketika bergabung dalam IPI.
Untuk itulah peran IPI dalam dunia perpustakaan dan kepustakawan dirasa sangat strategis. IPI diharapkan sebagai lembaga penaung pustakawan, menjawab dan menyelesaiakan segala permasalahan yang dihadapi oleh pustakawan termasuk juga memberi sanksi bagi pustakawan (bila diperlukan) apabila melanggar peraturanperaturanyang telah dibuat. Kemudian IPI juga diharapkan dapat bekerja sama dengan organisasi profesi yang lain sehingga profesi pustakawan lebih dikenal di dunia luar. Karena sebuah organisasi profesi tidak mungkin berdiri sendiri tanpa didukung oleh organisasi profesi yang lain.

Untuk itulah sudah seharusnya para pustakawan profesional bersama-sama dengan IPI berjalan tegak bersama-sama untuk memajukan dunia perpustakaan di Indonesia. Menghilangkan imej bahwa profesi pustakawan adalah "aneh", "salah pilih", ataupun "buangan". Melalui IPI, para pustakawan dapat menyalurkan ide-ide kreatif untuk menjawab tantangan pengguna, dapat sharing dengan sesama 
pustakawan, menemukan solusi untuk segala permasalahan yang ada di perpustakaan.

\section{Penutup}

Perkembangan teknologi informasi yang semakin pesat membuat perpustakaan sebagai salah satu lembaga penyedia informasi harus memikirkan bentuk dan ide-ide kreatif agar dapat menjawab kebutuhan para penggunanya yang semakin cepat. Tuntutan informasi yang cepat, tepat dan akurat yang harus disediakan oleh perpustakaan sudah tidak bisa ditawar lagi apabila perpustakaan tidak ingin ditinggalkan penggunanya. Untuk itulah seorang pustakawan profesional diperlukan untuk menjawab tantangan yang diberikan dengan memanfaatkan adanya teknologi informasi.

Sudah bukan lagi jamannya pustakawan hanya berkutat pada kegiatan sehari-hari di perpustakaan. Pustakawan yang hanya hidup di dunianya sendiri tanpa mau beradaptasi dengan dunia luar. Hadirnya teknologi informasi bukan sebagai momok tetapi lebih sebagai sarana yang membantu pustakawan untuk menjalankan tugasnya.

Pustakawan profesional adalah pustakawan yang memenuhi beberapa standar kompetensi antara lain yang memiliki latar belakang pendidikan yang sesuai, bersikap terbuka terhadap hal-hal baru, kreatif dan yang terpenting mau belajar. Dengan demikian seorang pustakawan profesional dapat mengukur dirinya sendiri apakah sudah memenuhi kompetensi yang dimaksud untuk selanjutnya dipikirkan apakah sudah ada penghargaan ataupun reward yang pantas diterima karena profesinya tersebut.

Salah satu poin dalam syaratsyarat profesi adalah adanya adanya organisasi profesi. Ikatan Pustakawan Indonesia sebagai organisasi profesi pustakawan di Indonesia sebenarnya mempunyai peran strategis dalam upayanya memajukan dunia perpustakaan dan kepustakawanan di Indonesia. Ke depan diharapkan keberadaan IPI bisa merangkul pustakawan dari segala lapisan. Dengan demikian pustakawan tidak merasa minder untuk mengakui profesinya. 
Kini, sudah saatnya para pustakawan profesional bergerak bersama-sama dengan IPI berjuang memajukan dunia perpustakaan dan kepustakawanan di Indonesia. Bersama-sama melakukan berbagai kegiatan seperti sosialisasi agar profesi pustakawan semakin dikenal dimasyarakat kita sendiri dan juga para pustakawannya tidak hanya bermimpi untuk menjadikan perpustakaan seperti yang sudah ada di luar negeri. Bukan perkara mudah memang, tetapi bukan berarti tidak bisa kan? Maju dunia perpustakaan di Indonesia!!!!

\section{F. Daftar Pustaka}

Basuki, Sulistyo. 1993. Pengantar Ilmu Perpustakaan.Jakarta: Universitas Terbuka, Depdikbud

Harmawan. 2008. Kompetens Pustakawan: antara harapan dan kerisauan. Makalah Seminar

Nasional tentang Kompetensi dan Sertifikasi Profesi Pustakawan, 14 Oktober 2008.

Surakarta: UPT

\section{Perpustakaan UNS}

Hastjarjo, Sri. 2009. Membangun dan Mengelola Perpustakaan Masa Depan. Makalah Bedah Buku yang diadakan oleh FISIP UNS, 14 Desember 2009. Surakarta: FISIP UNS

Lasa, HS. 1996. Memantapkan Jabatan Fungsional Pustakawan. Makalah Seminar

Pustakawan UGM, 13 Januari. Yogyakarta: UPT Perpustakaan UGM

Supriyanto.2008. Kompetensi \& Sertifikasi Profesi Pustakawan Implikasi UU Perpustakaan No. 32 Tahun 2007. Makalah Seminar Nasional tentang Kompetensi dan Sertifikasi Profesi Pustakawan, 14 Oktober 2008. Surakarta: UPT Perpustakaan UNS

Undang-Undang No. 43 Tahun 2007 Tentang Perpustakaan 
Website

http://davidrothman.net/2010/05/04

/professional-librarian

diakses tanggal 20 Agustus 2010

http://nurbayanti.blogspot.com/200

9/01/membangun-profesi- pustakawan-yang.html

diakses tanggal 20 Agustus 2010

http://www.ipi.or.id diakses tanggal 20 Agustus 2010

$-^{* * * * *}$ 